\title{
Facial emotion recognition and its association with symptom severity, functionality, and cognitive impairment in schizophrenia: preliminary results
}

\author{
Johanna Vanessa Suárez-Salazar, ${ }^{1}$ Ana Fresán-Orellana, ${ }^{2}$ Ricardo Arturo Saracco-Álvarez ${ }^{3}$
}

Dirección de Enseñanza, Instituto Nacional de Psiquiatría Ramón de la Fuente Muñíz, Ciudad de México, México.

2 Laboratorio de Epidemiología Clínica, Subdirección de Investigaciones Clínicas, Instituto Nacional de Psiquiatría Ramón de la Fuente Muñíz, Ciudad de México, México.

${ }^{3}$ Clínica de Esquizofrenia, Instituto Nacional de Psiquiatría Ramón de la Fuente Muñíz, Ciudad de México, México.

Correspondence:

Ricardo A. Saracco-Álvarez

Clínica de Esquizofrenia, Dirección de Servicios Clínicos.

Calzada México-Xochimilco 101, San Lorenzo Huipulco, Tlalpan, 14370, Ciudad de México.

Phone: +52 (55) 4160 - 5263

Email: dr_saracco@yahoo.com.mx

Received: 21 June 2019

Accepted: 10 February 2020

Citation:

Suárez-Salazar, J. V., Fresán-Orellana, A., \& Saracco-Álvarez, R. A. (2020) Facial emotion recognition and its association with symptom severity, functionality, and cognitive impairment in schizophrenia: preliminary results. Salud Mental, 43(3), 105-112.

DOI: $10.17711 /$ SM.0185-3325.2020.015

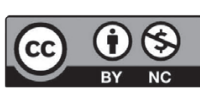

\begin{abstract}
Introduction. There is evidence to suggest that individuals with schizophrenia have greater difficulty in recognizing facial emotions, which has been related to cognitive impairment and higher symptom severity in this disease and seems to lead to a worse functional prognosis. Objective. To determine the association between facial emotion recognition and symptom severity, functionality, and cognitive impairment in a sample of schizophrenic patients. Method. This is an observational, cross-sectional, and correlational study conducted on 72 patients. The following scales: PANSS, MOCA, ERI, and FACT-Sz were used to assess symptom severity in schizophrenia, cognitive functioning, facial emotion recognition, and functionality, respectively. The Pearson Correlation Coefficient was used to measure the linear association between all variables. Results. Overall, moderate symptom severity and mild cognitive and functional disability were found. The most frequently recognized emotion was joy $(70 \%)$ and the least frequently recognized one was anger. A positive association was also found between anger recognition and severity of the PANSS cognitive subscale $(r=-.24, p=.03)$, sadness recognition and severity of the PANSS negative subscale $(r=-.24, p=.03)$, and the FACT-Sz score and fear recognition $(r=.31, p=.008)$. Discussion and conclusion. The present study yields preliminary results that provide a broader perspective on facial emotion recognition and, indirectly, social interaction and functionality in people with schizophrenia.
\end{abstract}

Keywords: Schizophrenia, facial recognition, cognitive dysfunction, emotions.

\section{RESUMEN}

Introducción. Existe evidencia de que los pacientes con esquizofrenia tienen mayor dificultad para reconocer las emociones faciales, lo cual se ha relacionado con el deterioro cognitivo que se manifiesta en esta enfermedad y con una mayor gravedad sintomática, que parece dar lugar a un peor pronóstico funcional. Objetivo. Determinar la asociación del reconocimiento facial de emociones con la gravedad sintomática, funcionalidad y deterioro cognitivo en un grupo de pacientes con esquizofrenia. Método. Un estudio observacional, transversal y correlacional realizado con 72 pacientes. Se utilizaron las escalas: PANSS, MOCA, ERI y FACT-Sz para evaluar la gravedad sintomática, el funcionamiento cognitivo, el reconocimiento facial de emociones y la funcionalidad, respectivamente. Se utilizó el Coeficiente de Correlación de Pearson para medir la asociación lineal entre dichas variables. Resultados. Se encontró de forma global una gravedad sintomática moderada y una discapacidad cognitiva y funcional leve. La alegría fue la emoción más reconocida $(70 \%)$ y la ira la menos reconocida. Se encontró una asociación positiva entre el reconocimiento de la ira y la gravedad de la subescala cognitiva de la PANSS $(r=-.24, p=.03)$, el reconocimiento de la tristeza y la gravedad de la subescala negativa de la PANSS $(r=-.24, p=.03)$, y la puntuación de la FACT-Sz y el reconocimiento del miedo $(r=.31, p=.008)$. Discusión y conclusión. El presente estudio muestra algunos resultados preliminares que nos permiten tener una perspectiva más amplia de lo que ocurre con el reconocimiento facial de emociones en la esquizofrenia y, de forma indirecta, en la interacción social y la disfunción que presentan quienes lo padecen.

Palabras clave: Esquizofrenia, reconocimiento facial, deterioro cognitivo, emociones. 


\section{INTRODUCTION}

Schizophrenia is a complex, multicausal syndrome affecting approximately $1 \%$ of the population worldwide. It is estimated that between seven and eight individuals out of every 1000 present this disorder across the lifespan (Saha, Chant, Welham, \& McGrath, 2005), which is characterized by positive, negative and cognitive symptoms that cause psychosocial dysfunction in individuals who suffer from it (Addington \& Addington, 1993).

Facial emotion recognition refers to the skill of recognizing basic emotions in other people's faces and is a part of the social construct called social cognition (Kee, Horan, Wynn, Mintz, \& Green, 2006; Russell, 1994). Certain basic and pancultural emotions such as joy, sadness, fear, disgust, surprise, and anger have been identified (Ekman \& Friesen, 1986).

Several studies have shown that patients with schizophrenia experience difficulty with facial emotion recognition (Pérez-Rincón, Cortés, \& Díaz-Martínez, 1999), as do their first-degree relatives (Chan, Li, Cheung, \& Gong, 2010; Saracco-Alvarez, Fresán, \& Escamilla-Orozco, 2013), which points to the possibility of a shared genetic load (Mendoza et al., 2011). It has even been thought that facial emotion recognition may be the key to understanding social dysfunction in schizophrenia (García, Aliste, \& Soto, 2018) and therefore be a predictive variable of functional prognosis (On, Cotton, Farhall, Killackey, \& Allot, 2016). There is also evidence that patients with schizophrenia are slower than controls in tasks involving facial emotion recognition (Watanuki et al., 2016) and that they recognize positive emotions such as joy better and more frequently, and have difficulty recognizing negative facial emotions such as anger, fear, sadness, and disgust (Jetha, Zheng, Goldberg, Segalowitz, \& Schmidt, 2013; Romero-Ferreiro et al., 2016). It has been observed that patients with schizophrenia regulate their behavior based on the facial affect they perceive, and that the main difficulty lies in the interpretation of neutral faces, which could lead to punitive behaviors, being this one of the underlying mechanisms that could explain psychosocial dysfunction (Tse, Lu, Bond, Chan, \& Tam, 2011). However, a study, in which patients with schizophrenia with and without violent behavior were compared, found no difference in reaction time or accuracy in emotion recognition (Demirbuga et al., 2013).

Cognitive functioning has also been described as a predictive variable of the functional prognosis of schizophrenia, even in healthy individuals with a high risk of psychosis (Bora, Yalincetin, Akdede, \& Alptekin, 2018; Rund, 2018). Since patients with schizophrenia usually show a significant decrease in cognition from the onset of the disease and even before (Corigliano et al., 2014), their evaluation during the course of the disease is essential. The association between cognitive impairment in schizophrenia, alterations in social interaction and in the processing, identification, and interpretation of emotions, however, is as yet unclear (García et al., 2018; Hooker \& Park, 2002).

Given the increasing importance of social cognition in the course, prognosis, and functionality of patients with schizophrenia, the objective of the present study was to determine the association between facial emotion recognition and recognition time and symptom severity, functionality and cognitive impairment in a group of patients with schizophrenia.

The study hypothesis was that lesser and later facial recognition of negative emotions would be associated with greater symptom severity, lower functionality and greater cognitive impairment in patients with schizophrenia.

\section{METHOD}

\section{Study design}

This is a across-sectional, descriptive, correlational study (Hernández, Fernández, \& Baptista, 2014).

\section{Sample description and study location}

Considering an a priori power analysis with a bilateral research hypothesis, a total sample of 72 patients with an effect size of at least .3 was calculated (Cohen, 2013), with $90 \%$ statistical power and an estimated error of $15 \%$. Subjects included patients aged 18 to 59 years old from the Schizophrenia Clinic of the Instituto Nacional de Psiquiatría Ramón de la Fuente Muñiz in Mexico City, with a diagnosis of schizophrenia according to the DSM-5 diagnostic criteria, with less than 15 years of evolution of the disease, and a total score between 60 and 120 points on the PANSS scale, under treatment with the same antipsychotic for at least three months. Those with a psychiatric comorbidity except for tobacco and caffeine use disorder, those who did not speak Spanish, who were unable to read or write, who had a neurological disease and/or a disorder of the visual or auditory system that prevented the adequate performance of assessment instruments, or who were aggressive or agitated during interviews were excluded. Participants who failed to complete the evaluations were removed from the study.

\section{Measurements}

The age, gender, educational attainment, marital status, occupation, socioeconomic level, age at onset of the condition, duration of untreated psychosis (DUP), hospitalizations, and psychiatric medication used at the time of the study of each patient were evaluated.

The five-dimension version of the Positive and Negative Schizophrenia Syndrome (PANSS) scale: positive, neg- 
ative, cognitive, anxiety/depression, and excitability, was used to assess the symptomatic severity of schizophrenia. The instrument comprises 30 items evaluated on a Likert scale with seven response options, where a higher score indicates greater symptom severity. In Mexico, the scale showed adequate concurrent and construct validity of the five dimensions, as well as internal consistency of over .80 (Fresán et al., 2005).

Facial emotion recognition was assessed by the facial subtest of the Emotion Recognition Index (ERI). This computerized instrument evaluates the ability of individuals to correctly infer the emotions an actor represents in facial expressions of emotion. The authors selected the expressions of joy, sadness, fear, anger, and disgust, since these emotions are regarded as basic and universal, and therefore play an important role in human behavior in response to their social environment (Ekman, 1992). Both the number of correct answers each subject gave when presented with 30 photographs of facial expression of emotions were measured, as well as the reaction time for responding to each photo. The instrument was validated by using most of the instruments available in the area, showing a significant correlation between ERI and its subscales $(\mathrm{r}=.383, p<.001)$, with instruments such as JACFEE (Japanese and Caucasian Facial Expressions of Emotion) and MERT (Multimodal Emotion Recognition Test) (Scherer \& Scherer, 2011). Although no studies were found among Latino population using ERI, it was decided to use it because the images for assessing facial emotion recognition were the same as those in other instruments previously used in Mexico, such as POFA (Pictures of Facial Affect) by Ekman and Friesen (1976), and also because of it provided free access to software for research purposes, computerization of the program to accurately determine reaction time in recognizing the emotions evaluated, the option of configuring the program in Spanish and accessibility for directly downloading the test results onto a spreadsheet.

The Montreal Cognitive Assessment Scale (MoCA) assesses the cognitive functioning of participants in the areas of executive functions, visuospatial skills, identification, memory, attention, language, abstraction, memory, and orientation in 30 items. A cut-off point of 26 points in the total score has been suggested to identify the presence of cognitive impairment. In 2014, this scale was validated in Mexico as a useful tool for screening mild cognitive impairment in patients with schizophrenia, with a Cronbach's alpha value of .71 and adequate concurrent validity (Rodríguez-Bores Ramírez, Saracco-Álvarez, Escamilla-Orozco, \& Fresán Orellana, 2014).

Lastly, the Functional Assessment for Comprehensive Treatment of Schizophrenia (FACT-Sz) was used to evaluate the psychosocial functioning of an individual with schizophrenia, with a score ranging from zero to 100 . The cut-off point of 60 indicates that those with a higher score have acceptable performance, a score of over 70 indicates slight functional impairment, over 80 indicates functional recovery, while scores below 60 indicate moderate to severe functional impairment. The instrument has shown adequate convergent validity with symptomatic severity scales and concurrent validity with functionality scales, with a high intraclass correlation coefficient (.966, $p<.0001)$ (Suzuki et al., 2008). This instrument was previously used in Mexican population in a study comparing patients with schizophrenia according to their functionality to determine the association between the latter and treatment response and resistance (Garay, 2013).

\section{Procedure}

All subjects who met the selection criteria voluntarily signed an informed consent form. The study instruments were applied during a 90-minute period. This procedure was performed by a doctor with a specialization in psychiatry.

\section{Statistical analysis}

The description of the clinical-demographic characteristics of the sample was undertaken with frequencies and percentages for the categorical variables, and with means and standard deviations for the continuous variables. Pearson's Correlation Coefficient was used to determine the linear association between the percentage of emotion recognition, recognition time (msec), and symptom severity, cognitive functioning, and functionality. The level of statistical significance was set at $p<.05$.

\section{Ethical considerations}

This study was conducted in accordance with the general principles stated in the Declaration of Helsinki (World Medical Association, 2013), with the approval of the Research Ethics Committee of the Instituto Nacional de Psiquiatría Ramón de la Fuente Muñiz in Mexico (CEI/C/083/2016).

\section{RESULTS}

\section{Clinical-demographic characteristics of the sample}

Seventy-two patients with schizophrenia with an average age of 32.4 years were included. Just over $50 \%$ were men and over $60 \%$ were unemployed. The age of onset of the disorder reported was 24 years, with an average duration of untreated psychosis (DUP) of nearly one year (50 weeks). All patients were under treatment with antipsychotics at the time of the study.

Regarding symptom severity, functionality, and cognition, patients showed moderate symptom severity and mild 
Table 1

Clinical-demographic characteristics of sample

\begin{tabular}{|c|c|c|c|}
\hline \multicolumn{4}{|c|}{ Demographic and Clinical Variables } \\
\hline & $n$ & & $\%$ \\
\hline \multicolumn{4}{|l|}{ Sex } \\
\hline Men & 39 & & 54.2 \\
\hline Women & 33 & & 45.8 \\
\hline \multicolumn{4}{|l|}{ Marital status } \\
\hline Unpartnered & 64 & & 88.9 \\
\hline \multicolumn{4}{|l|}{ Socio-economic status } \\
\hline Middle & 49 & & 68.1 \\
\hline \multicolumn{4}{|l|}{ Occupation } \\
\hline Unpaid & 50 & & 69.4 \\
\hline \multicolumn{4}{|l|}{ Psychiatric hospitalization } \\
\hline Yes & 40 & & 55.5 \\
\hline Atypical antipsychotics & 60 & & 83.3 \\
\hline Antidepressants & 31 & & 43.1 \\
\hline Benzodiazepines & 14 & & 19.4 \\
\hline Correctors & 12 & & 16.7 \\
\hline \multirow[t]{2}{*}{ Modulators } & 9 & & 12.5 \\
\hline & Mean & $S D$ & Range \\
\hline Age (years) & 32.4 & 9.5 & $19-59$ \\
\hline Educational attainment (years) & 13 & 3.2 & $5-24$ \\
\hline Age of onset (years) & 24 & 8.8 & $13-52$ \\
\hline DUP (weeks) & 50.3 & 85.6 & $1-364$ \\
\hline \multicolumn{4}{|c|}{ Symptom severity, cognition and functionality } \\
\hline Scales & Mean & $S D$ & Range \\
\hline \multicolumn{4}{|l|}{ PANSS } \\
\hline Positive & 21.0 & 5.0 & $12-38$ \\
\hline Negative & 20.9 & 4.8 & $10-36$ \\
\hline Cognitive & 16.9 & 3.2 & $11-30$ \\
\hline Excitability & 6.4 & 2.4 & $4-13$ \\
\hline Depression\& Anxiety & 9.0 & 2.8 & $4-16$ \\
\hline Total & 74.2 & 11.9 & $60-112$ \\
\hline FACT-Sz Scale & 69.8 & 7.0 & $50-85$ \\
\hline MoCA Scale & 24.7 & 2.9 & $16-30$ \\
\hline
\end{tabular}

Note: $S D=$ Standard desviation

disability in terms of functionality, measured on the FACTSz scale, and cognition, measured using MoCA. A description of the main demographic and clinical characteristics is given in Table 1.

\section{Facial emotion recognition and recognition time}

The percentage of recognition of the five emotions (joy, sadness, fear, anger, and disgust) evaluated with ERI showed that joy was the only emotion recognized over $90 \%$ of the time by the subjects, while the least frequently recognized emotion was anger (Figure 1).

As for the total time for emotion recognition, joy was the emotion that was most quickly recognized while anger took the longest to be recognized (Figure 2).

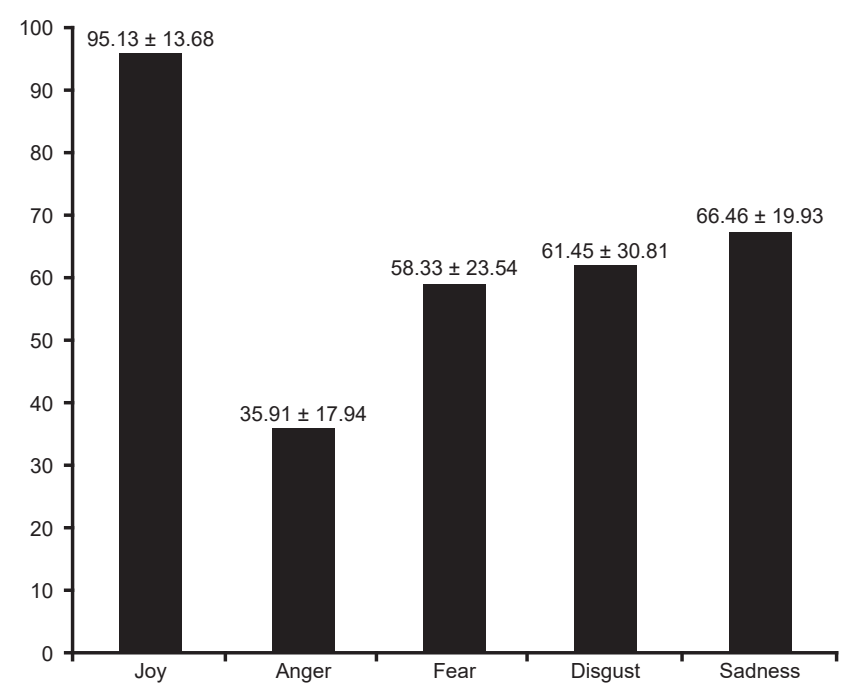

Figure 1. Percentage of Facial Emotion Recognition in Study Sample.

\section{Facial emotion recognition, functionality and symptom severity}

Three significant associations were found: between anger recognition and the severity of the PANSS cognitive subscale $(\mathrm{r}=-.24, p=.03)$; between sadness recognition and the severity of the PANSS negative subscale $(\mathrm{r}=-.24, p=.03)$; and between the FACT-Sz score and fear recognition $(\mathrm{r}=.31$, $p=.008$ ). Associations were also found between the time for emotion recognition and symptom severity at the time of the study. The PANSS subscales of positive symptoms and anxiety/depression symptoms showed no correlations with the time for emotion recognition, while the subscale of cognitive symptoms and overall severity (total PANSS) showed associations with the time for recognition of all emotions (Table 2).

\section{DISCUSSION AND CONCLUSION}

The purpose of this study was to determine the association between facial emotion recognition and time for emotion recognition and symptom severity, functionality, and cognitive functioning in a group of patients with schizophrenia. Schizophrenia has generally been described as a disorder that causes social and occupational dysfunction related to early age of onset (Daltio, Attux, \& Ferraz, 2015). This prevents patients from achieving certain social goals, such as working, having a partner, or studying (Corredor Rozo et al., 2013). These findings agree with our study, in which over $60 \%$ of the sample was not engaged in a paid activity, had slight functional disability, and an average age of onset of the disorder of 24.

Symptom severity, as measured by PANSS showed that overall patients presented with moderate severity (with a total score of 74.2, $S D$ 11.9), probably related to the recruit- 


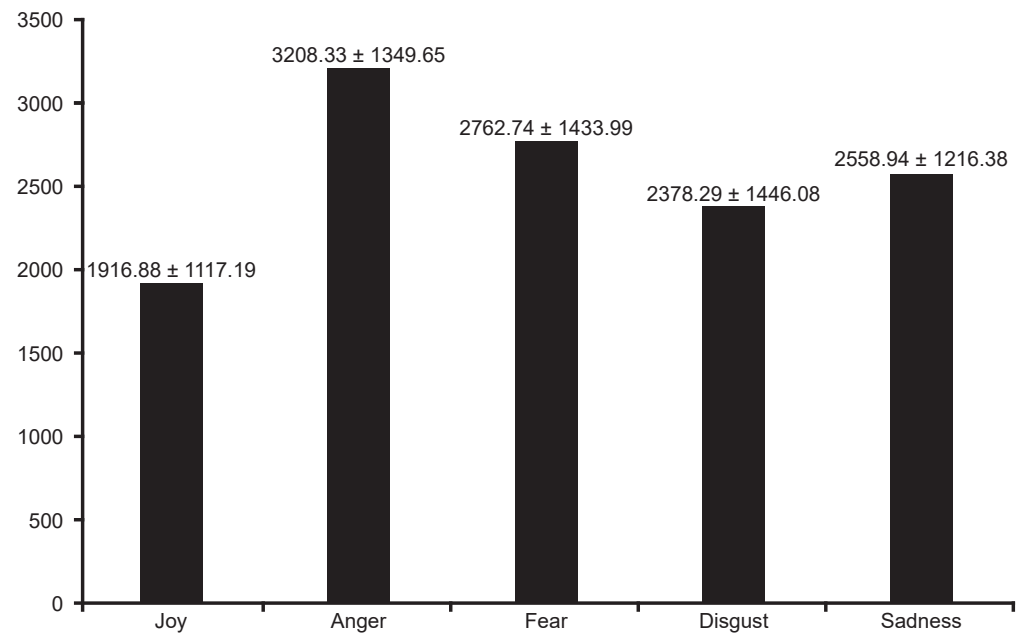

Figure 2. Average length of time for facial emotion recognition (msec).

ment of patients, since all patients had been treated with the same antipsychotic for at least three months. Moreover, patients maintained good adherence to treatment and none of them experienced an acute episode or relapse during the evaluation.

At the same time, the evaluation of cognition measured by the MoCA scale reported mild cognitive impairment across the sample. This score had a wide range (1630 points), probably secondary to the heterogeneity of the sample mainly in terms of age range (19-59 years), educational attainment (5-24 years of study) and DUP (1-364 weeks). Regarding the influence of age on the MoCA score, there are reports of an inverse association between age and score (Aguilar-Navarro et al., 2018), while for educational attainment, there are studies that suggest modifying the cut-off point according to subjects' level of schooling (Gómez, Zunzunegui, Lord, Alvarado, \& García, 2013). Other authors point out that no adaptation regarding schooling is required, since the cut-off point of 26 applied in people with low educational attainment has a sensitivity and specificity of $>80 \%$, although they do not recommend it as a screening instrument for individuals with very low schooling (Ju- layanont et al., 2015). As for DUP and cognitive function, although this is not entirely clear, it has been reported that the greater the DUP, the greater the cognitive impairment (García, Fresán-Orellana, Medina-Mora, \& Ruiz, 2008).

In our study, regarding facial emotion recognition and the time required for the latter, it was found that joy was the most frequently recognized emotion $(>90 \%)$ and took the least time to be identified, unlike anger, which was the least frequently recognized and required more time to be identified. These results are comparable to those of other publications, which state that, in schizophrenia, the most common pattern is the recognition of positive expressions, and that subjects experience greater difficulty recognizing negative emotions (Romero-Ferreiro et al., 2016; Jetha et al., 2013; Namiki et al., 2007). A systematic review and meta-analysis found that fear was the least frequently identified emotion, followed by disgust, sadness, and anger. It should be noted that this pattern was similar to that of healthy controls, but higher in patients with early onset psychosis (Barkl, Lah, Harris, \& Williams, 2014).

When the association between the variables of facial emotion recognition and the severity of schizophrenia symp-

Table 2

Time for recognition and symptom severity

\begin{tabular}{|c|c|c|c|c|c|c|c|c|c|c|}
\hline \multirow[b]{3}{*}{ Scales } & \multicolumn{10}{|c|}{ Time for recognition - $m s e c$} \\
\hline & \multicolumn{2}{|c|}{ Joy } & \multicolumn{2}{|c|}{ Anger } & \multicolumn{2}{|c|}{ Fear } & \multicolumn{2}{|c|}{ Disgust } & \multicolumn{2}{|c|}{ Sadness } \\
\hline & $r$ & $p$ & $r$ & $p$ & $r$ & $p$ & $r$ & $p$ & $r$ & $p$ \\
\hline Negative PANSS & \multicolumn{2}{|c|}{ NS } & \multicolumn{2}{|c|}{ NS } & \multicolumn{2}{|c|}{ NS } & .31 & .007 & .30 & .01 \\
\hline Cognitive PANSS & .43 & .001 & .23 & .04 & .42 & .001 & .26 & .02 & .27 & .02 \\
\hline Excitability PANSS & \multicolumn{2}{|c|}{ NS } & \multicolumn{2}{|c|}{ NS } & \multicolumn{2}{|c|}{ NS } & \multicolumn{2}{|c|}{ NS } & .27 & .01 \\
\hline Total PANSS & .33 & .004 & .30 & .009 & .36 & .001 & .33 & .004 & .37 & .001 \\
\hline FACT-Sz & -.24 & .03 & -.25 & .03 & -.33 & .004 & \multicolumn{2}{|c|}{ NS } & \multicolumn{2}{|c|}{ N.S. } \\
\hline MOCA & \multicolumn{2}{|c|}{ NS } & \multicolumn{2}{|c|}{ NS } & -.29 & .01 & -.34 & .003 & \multicolumn{2}{|c|}{ N.S. } \\
\hline
\end{tabular}

Note: $N S=$ Not significant. 
toms was examined, overall, lower facial emotion recognition was observed in subjects with higher symptom severity, confirming part of the hypothesis proposed at the start of the study. Facial emotion recognition difficulties in schizophrenia are multifactorial and may be linked to the neurobiology of schizophrenia, since alterations in brain circuits that tend to be deactivated or activated, depending on the affective valence of a given emotion, have been described. Although findings are contradictory, some functional imaging studies report the deactivation of these circuits, especially in response to negative emotions, linked to the greater difficulty in identifying them (Watanuki et al., 2016). Like these studies, ours found an inverse association between anger and sadness recognition and symptom severity, specifically through the PANSS cognitive and negative subscales respectively.

The positive association between the time required for facial emotion recognition and the cognitive symptoms measured by PANSS, and the overall score of the scale, can be explained by the fact that individuals with schizophrenia present with cognitive symptoms to a greater or lesser degree, such as decreased processing, attention and reasoning speed (Rodriguez-Jimenez et al., 2015), which could interfere with the time they take to recognize facial emotions. Another explanation, albeit with inconsistent findings, is that the time required for facial emotion recognition is modified by the pharmacological treatment of schizophrenia (Sachse et al., 2014), which could have an indirect relationship with the symptom severity of schizophrenia, since clinical guidelines suggest optimizing treatment doses or adding another adjuvant drug to manage symptoms of the disorder. This increases the likelihood of adverse pharmacological effects that would lead to psychomotor slowing and increased time for facial emotion recognition.

Additionally, a significant, positive association was found between a subject's score on the FACT-Sz scale of functionality and the percentage of fear recognition. Patients who are less able to recognize this emotion have worse social functioning. Although no studies have found a similar association specifically with fear, some report that facial emotion recognition deficits in schizophrenia are associated with poor social functioning, since the ability to infer emotional states in others is a basic skill in the interaction between individuals and the formation of emotional bonds, which, since they are altered in schizophrenia and are persistent, also cause greater psychological stress, low self-esteem, social isolation, and a worse functional prognosis (Romero-Ferreiro et al., 2016).

Given that this study presents preliminary results, it has several limitations. First, the associations found among the variables are low or moderate, making it difficult to establish an association that could be valid for all patients with schizophrenia. Moreover, as mentioned earlier, the enormous variability observed in demographic and clinical variables, such as educational attainment, age, and DUP, could have influenced the results of the cognitive evaluation, as well as bias the results related to facial emotion recognition. (Sachse et al., 2014). In this context, we consider that in future studies, it would be useful to evaluate cognitive functioning in a larger, more homogeneous sample of patients, to be able to generalize results.

At the same time, it should be noted that only the ERI facial subtest was used to measure the accuracy and time of facial emotion recognition, which could yield inconclusive results. Since facial expressions are not the only fundamental emotional stimulus in social interaction, it is necessary to include the context in which they are expressed. Thus, both visual scenes, body expressions, emotional words, and verbal description can affect facial emotion recognition (Xu et al., 2015). It is therefore suggested that the study of this variable be expanded to obtain more reliable results, since the ability to integrate information occurs in a multisensory way (Liu et al., 2016).

Another limitation is the tool used, ERI, since it did not include all the basic emotions to evaluate facial emotion recognition and used photographs of faces of black and white American actors taken in 1976. Some research papers indicate that cultural and ethnic factors influence facial emotion perception in patients with schizophrenia, due to the existence of cultural differences in gauging the intensity of emotions and affective recognition (Li, Chan, Zhao, Hong, \& Gong, 2010). In order to avoid biases in this evaluation, it might be advisable to develop a facial expression recognition tool that includes Mexican actors or is based on existing Mexican photographs, such as those in Imágenes del Cuerpo (Body Images) (Pérez-Rincón, 1994). Another recommendation would be to include basic emotions such as surprise and a neutral expression (absence of emotional expression) and evaluate other parameters of this broad construct comprising emotion recognition in schizophrenia such as tone of voice.

This study presents preliminary results that have made it possible to accept the proposed hypothesis, which we consider could be important for understanding the social cognition of patients with schizophrenia in facial emotion recognition. The inclusion of the symptom severity of the disorder, cognition, and functionality provides a broader overview of the variables that may influence facial emotion recognition and indirectly the social interaction and dysfunction of patients with this complex condition.

\section{Funding}

None.

\section{Conflicts of interest}

The authors declare they have no conflicts of interest.

\section{Acknowledgements}

CONACYT and the Master's and Doctoral Program in Dental and Health Medical Sciences, UNAM. 


\section{REFERENCES}

Addington, J., \& Addington, D. (1993). Premorbid functioning, cognitive functioning, symptoms and outcome in schizophrenia. Journal of Psychiatry and Neuroscience, 18(1), 18-23.

Aguilar-Navarro, S. G., Mimenza-Alvarado, A. J., Palacios-García, A. A., SamudioCruz, A., Gutiérrez-Gutiérrez, L. A., \& Ávila-Funes, J. A. (2018). Validez y confiabilidad del MoCA (Montreal Cognitive Assessment) para el tamizaje del deterioro cognoscitivo en México. Revista Colombiana de Psiquiatría, 47(4), 237-243. doi: 10.1016/j.rcp.2017.05.003

Barkl, S. J., Lah, S., Harris, A. W., \& Williams, L. M. (2014). Facial emotion identification in early-onset and first-episode psychosis: A systematic review with meta-analysis. Schizophrenia Research, 159(1), 62-69. doi: 10.1016/j. schres.2014.07.049

Bora, E., Yalincetin, B., Akdede, B. B., \& Alptekin, K. (2018). Duration of untreated psychosis and neurocognition in first-episode psychosis: A meta-analysis. Schizophrenia Research, 193, 3-10. doi: 10.1016/j.schres.2017.06.021

Chan, R. C., Li, H., Cheung, E. F., \& Gong, Q. (2010). Impaired facial emotion perception in schizophrenia: A meta-analysis. Psychiatry Research, 178(2), 381-390. doi: 10.1016/j.psychres.2009.03.035

Cohen, J. (2013). Statistical power analysis for the behavioral sciences (Second Edition). New York: Lawrence Erlbaum Associates, Publishers. ISBN 0-80580283-5

Corigliano, V., De Carolis, A., Trovini, G., Dehning, J., Di Pietro, S., Curto, M., Donato, N., De Pisa, E., Girardi, P., \& Comparelli, A. (2014). Neurocognition in schizophrenia: From prodrome to multi-episode illness. Psychiatry Research, 220(1-2), 129-134. doi: 10.1016/j.psychres.2014.07.067

Corredor Rozo, Z. L., Sánchez Espinosa, M. P., Rondón Lagos, M., Páez Rojas, P. L., Cortés Duque C. I., \& Forero Castro, R. M. (2013). Estudio descriptivo de una muestra de pacientes con esquizofrenia residentes en el departamento de Boyacá, Colombia. Iatreia, 26(3), 245-256.

Daltio, C. S., Attux, C., \& Ferraz, M. B. (2015). Knowledge in schizophrenia: The Portuguese version of KAST (Knowledge About Schizophrenia Test) and analysis of social-demographic and clinical factors' influence. Schizophrenia Research, 168(1-2), 168-173. doi: 10.1016/j.schres.2015.07.009

Demirbuga, S., Sahin, E., Ozver, I., Aliustaoglu, S., Kandemir, E., Varkal, M. D., ... Ince, H. (2013). Facial emotion recognition in patients with violent schizophrenia. Schizophrenia Research, 144(1-3), 142-145. doi: 10.1016/j. schres.2012.12.015

Ekman, P. (1992). An argument for basic emotions. Cognition and Emotion, 6(3-4), 169-200. doi: 10.1080/02699939208411068

Ekman, P., \& Friesen, W. V. (1976). Pictures of facial affect. Palo Alto, CA: Consulting Psychologists Press.

Ekman, P., \& Friesen, W. V. (1986). A new pan-cultural facial expression of emotion. Motivation and Emotion, 10(2), 159-168. doi: 10.1007/bf00992253

Fresán, A., De la Fuente-Sandoval, C., Loyzaga, C., García-Anaya, M., Meyenberg, N., Nicolini, H., \& Apiquian, R. (2005). A forced five-dimensional factor analysis and concurrent validity of the Positive and Negative Syndrome Scale in Mexican schizophrenic patients. Schizophrenia Research, 72(2-3), 123-129. doi: 10.1016/j.schres.2004.03.021

Garay, I. (2013). Estudio comparativo de los pacientes con esquizofrenia según su funcionalidad de acuerdo a las escalas FACT-Sz, CGI, GAF, PANSS y su asociación con la respuesta y resistencia a tratamiento (tesis para titulación del curso de posgrado de alta especialidad en medicina: manejo integral de los trastornos esquizofrénicos). Universidad Nacional Autónoma de México, México.

García, I., Fresán-Orellana, A., Medina-Mora, M. E., \& Ruiz, G. M. (2008). Impact of Duration of Untreated Psychosis (DUP) in the course and outcome of schizophrenia. Salud Mental, 31(6), 479-485.

García, R. R., Aliste, F., \& Soto, G. (2018). Cognición social en esquizofrenia: aspectos cognitivos y neurobiológicos. Revista Colombiana de Psiquiatría, 47(3), 170-176. doi: 10.1016/j.rcp.2017.03.004

Gómez, F., Zunzunegui, M. V., Lord, C., Alvarado, B., \& García, A. (2013). Applicability of the MoCA-S test in populations with little education in Colombia. International Journal of Geriatric Psychiatry, 28(8), 813-820. doi: 10.1002/gps.3885
Hernández, R., Fernández, C., \& Baptista, P. (2014). Metodología de la Investigación (Sexta Edición). México D.F.: McGraw-Hill/Interamericana.

Hooker, C., \& Park, S. (2002). Emotion processing and its relationship to social functioning in schizophrenia patients. Psychiatry Research, 112(1), 41-50. doi: 10.1016/s0165-1781(02)00177-4

Jetha, M. K., Zheng, X., Goldberg, J. O., Segalowitz, S. J., \& Schmidt, L. A. (2013). Shyness and emotional face processing in schizophrenia: An ERP study. Biological Psychology, 94(3), 562-574. doi: 10.1016/j.biopsycho.2013.10.001

Julayanont, P., Tangwongchai, S., Hemrungrojn, S., Tunvirachaisakul, C., Phanthumchinda, K., Hongsawat, J., ... Nasreddine, Z. S. (2015). The Montreal Cognitive Assessment-Basic: A Screening Tool for Mild Cognitive Impairment in Illiterate and Low-Educated Elderly Adults. Journal of the American Geriatrics Society, 63(12), 2550-2554. doi: 10.1111/jgs.13820

Kee, K. S., Horan, W. P., Wynn, J. K., Mintz, J., \& Green, M. F. (2006). An analysis of categorical perception of facial emotion in schizophrenia. Schizophrenia Research, 87(1-3), 228-237. doi: 10.1016/j.schres.2006.06.001

Li, H., Chan, R. C., Zhao, Q., Hong, X., \& Gong, Q. (2010). Facial emotion perception in Chinese patients with schizophrenia and non-psychotic first-degree relatives. Progress in Neuro-Psychopharmacology and Biological Psychiatry, 34(2), 393400. doi: 10.1016/j.pnpbp.2010.01.007

Liu, T., Pinheiro, A. P., Zhao, Z., Nestor, P. G., McCarley, R. W., \& Niznikiewicz, M. (2016). Simultaneous face and voice processing in schizophrenia. Behavioural Brain Research, 305, 76-86. doi: 10.1016/j.bbr.2016.01.039

Mendoza, R., Cabral-Calderin, Y., Domínguez, M., Garcia, A., Borrego, M., Caballero, A., ... Reyes, M. M. (2011). Impairment of emotional expression recognition in schizophrenia: A Cuban familial association study. Psychiatry Research, 185(1-2), 44-48. doi: 10.1016/j.psychres.2009.10.006

Namiki, C., Hirao, K., Yamada, M., Hanakawa, T., Fukuyama, H., Hayashi, T., \& Murai, T. (2007). Impaired facial emotion recognition and reduced amygdalar volume in schizophrenia. Psychiatry Research: Neuroimaging, 156(1), 23-32. doi: 10.1016/j.pscychresns.2007.03.004

On, Z. X., Cotton, S., Farhall, J., Killackey, E., \& Allott, K. (2016). Relationship between duration of untreated psychosis and neurocognition and social cognition in first-episode psychosis. Schizophrenia Research, 176(2-3), 529532. doi: 10.1016/j.schres.2016.06.018

Pérez-Rincón, H. (1994). Imágenes del cuerpo (Segunda Edición). (pp. 230). México, D.F.: Fondo de Cultura Económica.

Pérez-Rincón, H., Cortés, J., \& Díaz-Martínez, A. (1999). El reconocimiento de la expresión facial de las emociones. Salud Mental, 22(1), 17-23.

Rodríguez-Bores Ramírez, L., Saracco-Álvarez, R., Escamilla-Orozco, R., \& Fresán Orellana, A. (2014). Validez de la Escala de Evaluación Cognitiva de Montreal (MoCA) para determinar deterioro cognitivo en pacientes con esquizofrenia. Salud Mental, 37(6), 517-522.

Rodriguez-Jimenez, R., Dompablo, M., Bagney, A., Santabárbara, J., Aparicio, A. I., Torio, I., ... Palomo, T. (2015). The MCCB impairment profile in a Spanish sample of patients with schizophrenia: Effects of diagnosis, age, and gender on cognitive functioning. Schizophrenia Research, 169(1-3), 116-120. doi: 10.1016/j.schres.2015.09.013

Romero-Ferreiro, M. V., Aguado, L., Rodriguez-Torresano, J., Palomo, T., RodriguezJimenez, R., \& Pedreira-Massa, J. L. (2016). Facial affect recognition in early and late-stage schizophrenia patients. Schizophrenia Research, 172(1-3), 177 183. doi: 10.1016/j.schres.2016.02.010

Rund, B. R. (2018). The research evidence for schizophrenia as a neurodevelopmental disorder. Scandinavian Journal of Psychology, 59(1), 49-58. doi:10.1111/ sjop. 12414

Russell, J. A. (1994). Is there universal recognition of emotion from facial expression? A review of the cross-cultural studies. Psychological Bulletin, 115(1), 102-141. doi: 10.1037/0033-2909.115.1.102

Sachse, M., Schlitt, S., Hainz, D., Ciaramidaro, A., Walter, H., Poustka, F., ... Freitag, C. M. (2014). Facial emotion recognition in paranoid schizophrenia and autism spectrum disorder. Schizophrenia Research, 159(2-3), 509-514. doi: 10.1016/j. schres.2014.08.030

Saha, S., Chant, D., Welham, J., \& McGrath, J. (2005). A Systematic Review of the Prevalence of Schizophrenia. PLoS Medicine, 2(5), e141. doi: 10.1371/journal. pmed.0020141 
Saracco-Alvarez, R., Fresán, A., \& Escamilla-Orozco, R. (2013). Facial emotion recognition in schizophrenia: A comparison with siblings and control subjects. Schizophrenia Research, 151(1-3), 291-292. doi: 10.1016/j.schres.2013.09.028

Scherer, K. R., \& Scherer, U. (2011). Assessing the Ability to Recognize Facial and Vocal Expressions of Emotion: Construction and Validation of the Emotion Recognition Index. Journal of Nonverbal Behavior, 35(4), 305-326. doi: 10.1007/s10919-011-0115-4

Suzuki, T., Uchida, H., Nomura, K., Takeuchi, H., Nakajima, S., Tanabe, A., Yagi, G., Watanabe, K., \& Kashima, H. (2008). Novel rating scales for schizophrenia - Targeted Inventory on Problems in Schizophrenia (TIP-Sz) and Functional Assessment for Comprehensive Treatment of Schizophrenia (FACT-Sz). Schizophrenia Research, 106(2-3), 328-336. doi: 10.1016/j.schres.2008.08.013

Tse, W. S., Lu, Y., Bond, A. J., Chan, R. C., \& Tam, D. W. (2011). Facial emotion linked cooperation in patients with paranoid schizophrenia: A test on the Interpersonal
Communication Model. International Journal of Social Psychiatry, 57(5), 509517. doi: 10.1177/0020764010371276

Watanuki, T., Matsuo, K., Egashira, K., Nakashima, M., Harada, K., Nakano, M., ... Watanabe, Y. (2016). Precentral and inferior prefrontal hypoactivation during facial emotion recognition in patients with schizophrenia: A functional nearinfrared spectroscopy study. Schizophrenia Research, 170(1), 109-114. doi: 10.1016/j.schres.2015.11.012

World Medical Association. (2013). Declaración de Helsinki - Principios éticos para las investigaciones médicas en seres humanos. 64ª Asamblea General. Fortaleza, Brasil.

Xu, Q., Yang, Y., Zhang, E., Qiao, F., Lin, W., \& Liang, N. (2015). Emotional conflict in facial expression processing during scene viewing: An ERP study. Brain Research, 1608, 138-146. doi: 10.1016/j.brainres.2015.02.047 